Primljen / Received: 21.5.2012

Ispravljen / Corrected: 20.11.2012.

Prihvaćen / Accepted: 29.11.2012.

Dostupno online / Available online: 15.12.2012.

\section{Environmentally-friendly self-compacting concrete}

Authors:

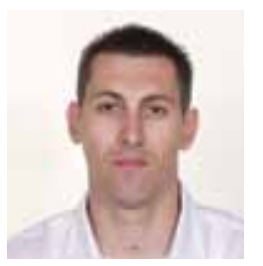

Assoc.Prof. Marijan Skazlić, PhD. CE

University of Zagreb

Faculty of Civil Engineering

skazle@grad.hr

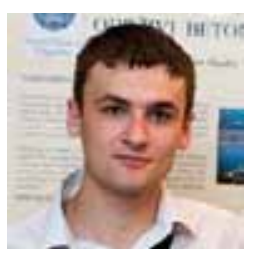

student Mario Vujica, univ.bacc.ing.aedif.

University of Zagreb

Faculty of Civil Engineering

mvujica.gradevina@gmail.com
Original scientific paper

\section{Marijan Skazlić, Mario Vujica}

\section{Environmentally-friendly self-compacting concrete}

An experimental analysis of properties of self-compacting concrete, for both fresh and hardened states of concrete, is presented in the paper. Concrete mixes differed according to the type and quantity of mineral admixtures (metakaolin, fly ash). It was established that the addition of fly ash and metakaolin greatly improves mechanical properties and durability of self-compacting concrete, and is favourable to environment due to reduction in $\mathrm{CO}_{2}$ emissions. Based on test results obtained, appropriate recommendations for practical application are given.

\section{Key words:}

$\mathrm{CO}_{2}$ emission, fly ash, metakaolin, mineral admixtures, sustainability, self-compacting concrete, durability

Izvorni znanstveni rad

\section{Marijan Skazlić, Mario Vujica}

\section{Samozbijajući ekološki prihvatljivi betoni}

U radu su eksperimentalno analizirana svojstva samozbijajućeg betona u svježem i očvrslom stanju. Betonske mješavine su se razlikovale prema vrsti i količini mineralnih dodataka (metakaolin, leteći pepeo). Utvrđeno je da dodatak letećeg pepela i metakaolina utječe na bitno poboljšanje trajnosnih i mehaničkih svojstava samozbijajućeg betona, te ekološki pozitivno djeluje na smanjenje emisije $\mathrm{CO}_{2}$. Na temelju dobivenih rezultata ispitivanja dane su preporuke za praktičnu primjenu.

Ključne riječi:

emisija $\mathrm{CO}_{2^{\prime}}$ leteći pepeo, metakaolin, mineralni dodaci, održivost, samozbijajući beton, trajnost

Wissenschaftlicher Originalbeitrag

\section{Marijan Skazlić, Mario Vujica}

\section{Selbstverdichtende umweltverträgliche Betone}

In der Arbeit werden die durch experimentelle Versuche erforschten Eigenschaften von selbstverdichtendem Beton in frischem und in erhärtetem Zustand beschrieben. Verschiedene Betonmischungen im Bezug auf die Art und die Menge der zugegebenen Mineralstoffe (Metakaolin, Flugasche) wurden betrachtet. Es wurde festgestellt, dass die Zugabe von Flugasche und Metakaolin wesentlich die Haltbarkeit und die mechanischen Eigenschaften von selbstverdichtendem Beton verbessert und eine ökologisch positive Auswirkung auf die Verringerung der CO2-Emission hat. Die erhaltenen Versuchsergebnisse werden als Grundlage der gegebenen Richtlinien für praktische Anwendungen angenommen.

\section{Schlüsselwörter:}

$\mathrm{CO}_{2}$-Emission, Flugasche, Metakaolin, Mineralstoffe, Nachhaltigkeit, selbstverdichtender Beton, Haltbarkeit 


\section{Introduction}

The self-compacting concrete is a new type of concrete that was initially developed and used in the late twentieth century. The basic characteristic of this concreting technology is that there is no need to use concrete compacting equipment when concrete is placed. Main advantages gained in this way are: reduced number of workers on construction site, faster realization of concrete works, much easier placing of concrete in zones characterized by dense reinforcement and/ or in zones of complex cross section, good appearance of the outside visible surface of concrete, and reduced level of noise at the construction site. Due to its numerous advantages when compared to ordinary concrete, this type of concrete has very soon become widely recognised in practice. This is why some experts in the field of materials and technology emphasize that the self-compacting concrete ranks among the most notable discoveries that have been made over the past several decades [1-11].

One of basic directions in which the research on self-compacting concrete is currently oriented is the improvement of its properties, with simultaneous improvement of environmental acceptability and sustainability of this material. This is mostly achieved through the use of various mineral admixtures. The research related to self-compacting concrete has so far mostly been concentrated around the type II mineral admixtures (silica fume, fly ash, slag), which are at the same time regulated by existing standards and codes [12-18].

Fly ash is obtained as a byproduct in thermal power plants. One of main advantages of concrete improved with fly ash is its environmental acceptability thanks to lower $\mathrm{CO}_{2}$ emissions.
Previous studies have revealed that the self-compacting concrete can be obtained by adding greater quantities of fly ash. This reduces the compressive strength, while durability and workability properties are mostly improved [16].

Metakaolin is a mineral admixture with a pozzolanic activity that is obtained by fabrication from kaolin clay. It is normally used in the quantity of 10 to 25 percent with respect to the total cement mass. Its environmental acceptability results from the fact that smaller $\mathrm{CO}_{2}$ emissions are generated during metakaolin production, when compared to cement production. This information becomes even more significant in the light of the fact that 5-7 percent of the total worldwide $\mathrm{CO}_{2}$ emissions are generated as a result of cement production. Test results have shown that mechanical and durability properties of ordinary concrete become better after addition of metakaolin. Research conducted to this effect has shown that early compressivestrength properties of the self-compacting concrete, and some of its durability properties (resistance to frost and salt, water permeability), are improved if metakaolin is added to concrete. Test production results have confirmed that the self-compacting concrete with 17.5 percent of metakaolin by cement weight is appropriate for production of prefabricated concrete elements. However, all durability properties of selfcompacting concrete, and change of its properties over time, have not so far been tested [19-22].

Self-compacting concrete compositions with various mineral admixtures (fly ash, metakaolin) are designed in this paper. Fibrillated polypropylene fibres are used due to their positive influence on the reduction of crack width and spacing in green concrete, which contributes to better durability of concrete.

Table 1. Concrete mix compositions

\begin{tabular}{|c|c|c|c|c|c|}
\hline \multirow{2}{*}{$\begin{array}{c}\text { Components } \\
{\left[\mathrm{kg} / \mathrm{m}^{3}\right]}\end{array}$} & \multicolumn{5}{|c|}{ Concrete mix marks } \\
\hline & SCC & SCC-F & SCC-M & SCC-FM & SCC-FMP \\
\hline Cement & 450 & 250 & 405 & 205 & 205 \\
\hline Fly ash & - & 200 & - & 200 & 200 \\
\hline Metakaolin & - & - & 45 & 45 & 45 \\
\hline Polypropylene fibres & - & - & - & - & 1 \\
\hline Water & 198 & 198 & 198 & 198 & 198 \\
\hline Water binding ratio & 0,44 & 0,44 & 0,44 & 0,44 & 0,44 \\
\hline Superplasticiser & 2,40 & 1,32 & 3,90 & 3,60 & 4,50 \\
\hline Mix stabiliser & 0,77 & 0,77 & 0,77 & 0,95 & 0,88 \\
\hline Filler & 150 & 150 & 150 & 150 & 150 \\
\hline Aggregate 0-4 mm & 816 & 818 & 814 & 814 & 813 \\
\hline Aggregate 4-8 mm & 328 & 329 & 328 & 328 & 327 \\
\hline Aggregate 8-16 mm & 468 & 469 & 467 & 467 & 467 \\
\hline
\end{tabular}


Components available on Croatian market have been used during experimental work in laboratory.

The influence of various admixtures on the properties of selfcompacting concrete were analysed at fresh and hardened state of concrete. Test results were used to determine advantages of individual concrete compositions with regard to concrete properties in hardened state.

Mechanical and durability properties of the self-compacting concrete, with admixtures and without admixtures, were compared for the same water binding ratio.

The results obtained show that the use of fly ash and metakaolin in self-compacting concrete is quite justified. Based on these results, appropriate recommendations were given for practical use of individual mixes of self-compacting concrete.

\section{Experimental work}

\subsection{Concrete mix compositions}

Five concrete mixes were subjected to experimental analysis. Concrete mix compositions are presented in Table 1. All mixes had the same water-binding ratio $(0.44)$ and the same quantity of binder. The three-fraction crushed aggregate was used in the mixes. The concrete composition was designed to meet environmental exposure classes XC4, XS3 and XD3, compressive strength class $C 50 / 60$, and the time-dependent settlement criterion SF3 $t_{500}<2.0 \mathrm{sec}$ (VS1).

The following marks were used for individual mixes:

- SCC: self-compacting concrete

- SCC-F: self-compacting concrete with fly ash

- SCC-M: self-compacting concrete with metakaolin

- SCC-FM: self-compacting concrete with fly ash and metakaolin

- SCC-FMP: self-compacting concrete with fly ash, metakaolin and polypropylene fibres.

\subsection{Testing objectives and program}

The objectives of the testing campaign were:

- design the self-compacting concrete composition using metakaolin and fly ash

- obtain experimentally the self-compacting concrete with various mineral admixtures (fly ash, metakaolin) using components available on Croatian market

- determine influence of fly ash on self-compacting concrete properties in fresh and hardened state

- determine influence of metakaolin on self-compacting concrete properties in fresh and hardened state

- determine influence of polypropylene fibres on selfcompacting concrete properties in fresh and hardened state

- determine influence of fly ash, metakaolin, and polypropylene fibres combination on self-compacting concrete properties in fresh and hardened state
- determine an optimum mix of self-compacting concrete with mineral admixtures

- compare properties of ordinary self-compacting concrete with those of self-compacting concrete with mineral admixtures and polypropylene fibres

- determine influence of the age of samples (28 and 90 days) on the mechanical and durability properties of selfcompacting concrete with and without mineral admixtures.

The following properties of the fresh concrete mixes were tested:

- density (HRN EN 12350-6)

- voids content (HRN EN 12350-7)

- temperature (HRN U.M1.032)

- consistency by flow table test (HRN EN 12350-8)

- V-funnel test (HRN EN 12350-9)

- L-box test (HRN EN 12350-10)

The flow table method is primarily used to test the filling property of the self-compacting concrete. The total diameter the concrete takes up by spreading is measured, and the time needed for the concrete to reach the horizontal diameter of $50 \mathrm{~cm}$ is determined. The L-box method is used to define the passing properties of the self-compacting concrete. The V-funnel method is used to determine the viscosity and filling capacity by measuring the time needed for the selfcompacting concrete to flow out of the $\mathrm{V}$-funnel.

The following test methods were used test properties in hardened state:

- compressive strength (HRN EN 12390-3)

- bending strength (HRN EN 12390-5)

- ultrasound pulse velocity (HRN EN 12504-4)

- capillary absorption (HRN U.M8.300)

- chloride diffusion (NT BUILD 492).

The experimental work was carried out in the laboratory of the Department for Materials of the Faculty of Civil Engineering University of Zagreb.

\subsection{Preparation technology and sample curing}

All mixes were prepared in the laboratory mixer 1001 in capacity.

After placing, the samples were freed from mould at 1 day, and the testing to be conducted after one day was performed (compressive strength). Other samples were cured in the wet chamber until the age of 28 and 90 days when the remaining tests of mechanical and durability properties were conducted.

\subsection{Components}

The Portland cement CEM 142.5 R was used in all mixes. A three-fraction aggregate made of crushed dolomite was used. The filler of dolomite origin, with most grains passing 


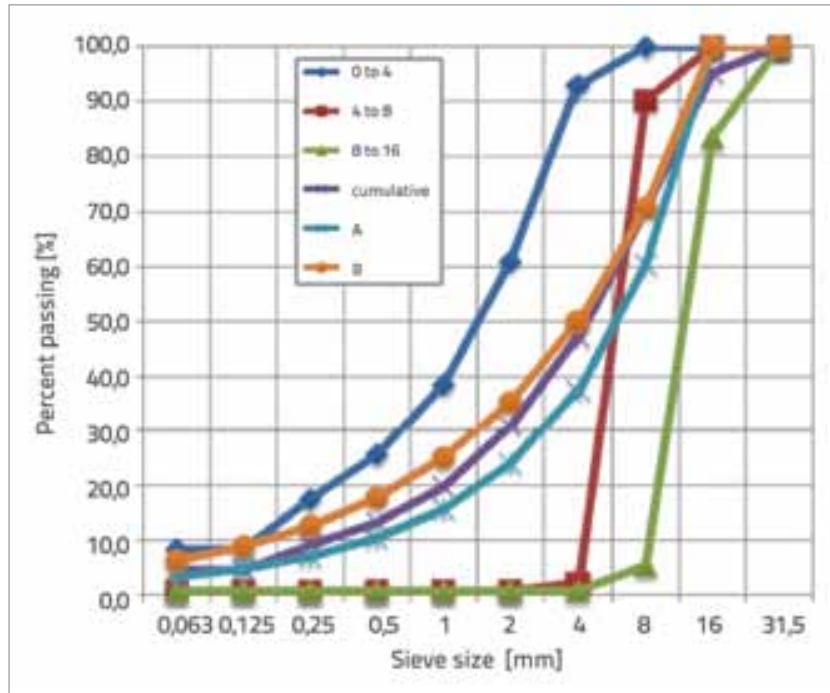

Figure 1. Grading of aggregate fractions

Table 2. Filler grading

\begin{tabular}{|c|c|c|c|c|c|}
\hline Sieve [mm] & 0.063 & 0.09 & 0.125 & 0.25 & 0.5 \\
\hline Passing [\%] & 64 & 81 & 91 & 99 & 100 \\
\hline
\end{tabular}

Table 3. Properties of individual components

\begin{tabular}{|c|c|c|c|c|}
\hline \multirow{2}{*}{ Property } & \multicolumn{3}{|c|}{ Components } \\
\cline { 2 - 5 } & CEM I 42,5 R & Fly ash & Metakaolin & Filler \\
\hline Ignition loss & $4,47 \%$ & $3,52 \%$ & $1,36 \%$ & $47,58 \%$ \\
\hline $\mathrm{SO}_{3}$ & $3,07 \%$ & $1,04 \%$ & $0,080 \%$ & $0,050 \%$ \\
\hline $\mathrm{SiO}_{2}$ & $19,90 \%$ & $46,84 \%$ & $52,95 \%$ & $0,23 \%$ \\
\hline $\mathrm{Fe}_{2} \mathrm{O}_{3}$ & $2,71 \%$ & $4,94 \%$ & $1,14 \%$ & $0,18 \%$ \\
\hline $\mathrm{Al}_{2} \mathrm{O}_{3}$ & $5,38 \%$ & $27,67 \%$ & $0,31 \%$ \\
\hline $\mathrm{CaO}^{*} \mathrm{MgO}$ & $60,23 \%$ & $9,65 \%$ & - & $30,38 \%$ \\
\hline $\mathrm{Cl}$ & $2,87 \%$ & $2,79 \%$ & - & $21,84 \%$ \\
\hline Density & $0,030 \%$ & $0,008 \%$ & $0,008 \%$ & $0,013 \%$ \\
\hline & $3,07 \mathrm{~kg} / \mathrm{dm}^{3}$ & $2,41 \mathrm{~kg} / \mathrm{dm}^{3}$ & $2,68 \mathrm{~kg} / \mathrm{dm}^{3}$ & $2,87 \mathrm{~kg} / \mathrm{dm}^{3}$ \\
\hline
\end{tabular}

Table 4. Limit values for testing concrete in fresh state

\begin{tabular}{|c|c|c|}
\hline Test method & Limit values & Class \\
\hline \multirow{3}{*}{ Flow table test $[\mathrm{mm}]$} & $550-650$ & SF1 \\
\hline \multirow{2}{*}{ Flow table test $t_{500}[\mathrm{~s}]$} & $660-750$ & SF2 \\
\cline { 2 - 3 } & $760-850$ & SF3 \\
\hline L-box & $<2$ & VS2 \\
\cline { 2 - 3 } & $\geq 2$ & PL1 (2 ribs), PL2 (3 ribs) \\
\hline \multirow{2}{*}{ V-funnel $[\mathrm{s}]$} & $\geq 0,80$ & VF1 \\
\hline
\end{tabular}

through the $0.125 \mathrm{~mm}$ sieve, was used. The aggregate and filler grading is shown in Figure 1 and Table 2 . Densities and chemical compositions of components are given in Table 3. Fibrillated polypropylene fibres $12 \mathrm{~mm}$ in length and $0.016 \mathrm{~mm}$ in diameter were used. The polycarboxylate superplasticiser and mix stabilizer were used as chemical admixtures.

\section{Test results}

\subsection{Test results in fresh state}

Fresh self-compacting concrete must have the following properties: filling ability, passing ability, and resistance to segregation. Limit values of test methods used for the selfcompacting concrete in fresh state are presented in Table 4, while the results obtained are given in Table 5. The realization of individual tests is presented in Figure 2.

Test results for the fresh self-compacting concrete show that all mixes have properties that are typical for the selfcompacting concrete. As to filling and passing abilities, mixes comply with classes SF3, VS1, PL2 and VF1. The resistance to segregation was checked by visual inspection of all mixes, and it was determined that this requirements has also been met by all mixes. The reduction in density can 
Table 5. Test results for fresh concrete

\begin{tabular}{|c|c|c|c|c|c|c|}
\hline \multirow{2}{*}{ Test method } & \multirow{2}{*}{ Unit } & \multicolumn{5}{|c|}{ Concrete composition designations } \\
\hline & & & SCC-F & SCC-M & SCC-FM & SCC-FMP \\
\hline Flow table test & $\mathrm{mm}$ & 760 & 790 & 760 & 785 & 775 \\
\hline Flow table test $t_{500}$ & s & 1,2 & 1,4 & 1,3 & 1,5 & 1,2 \\
\hline L-box & - & 0,80 & 0,86 & 0,82 & 0,90 & 0,83 \\
\hline V-funnel & s & 5,5 & 7,4 & 6,4 & 8,5 & 8,2 \\
\hline Air content & $\%$ & 0,80 & 1,60 & 1,20 & 1,60 & 1,20 \\
\hline Density & $\mathrm{kg} / \mathrm{m}^{3}$ & 2490 & 2430 & 2480 & 2420 & 2410 \\
\hline Temperature & ${ }^{\circ} \mathrm{C}$ & 22 & 23 & 21,8 & 23,5 & 23,6 \\
\hline
\end{tabular}
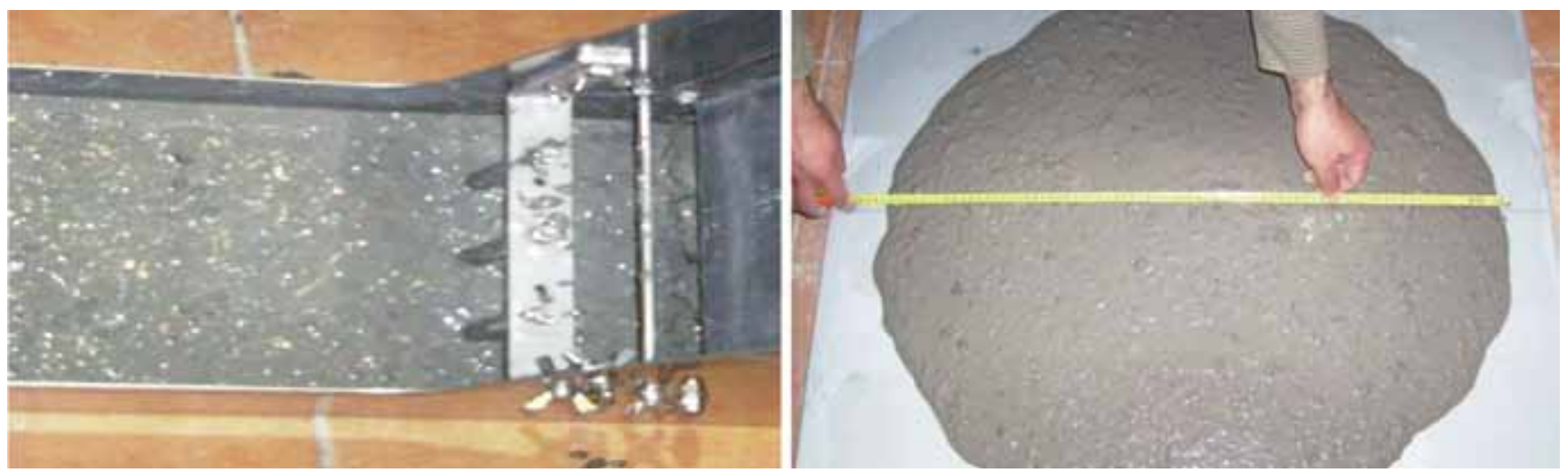

Figure 2. Self-compacting concrete testing by L-box (on the left) and by flow table (on the right)

be noted in self-compacting mixes with fly ash. This is due to lower density of fly ash when compared to concrete. The density of the mix with metakaolin is similar to that of the reference mix of the self-compacting concrete.

\subsection{Test results in hardened state}

Results obtained by testing mechanical and durability properties of self-compacting concrete are presented in Table

Table 6. Test results in hardened state

\begin{tabular}{|c|c|c|c|c|c|c|c|}
\hline Tested property & Unit & $\begin{array}{l}\text { Age of } \\
\text { sample }\end{array}$ & ScC & SCC-F & SCC-M & SCC-FM & SCC-FMP \\
\hline \multirow{3}{*}{$\begin{array}{l}\text { Compressive } \\
\text { strength }\end{array}$} & \multirow{3}{*}{$\mathrm{MPa}$} & 1 day & 40,1 & 16,9 & 38,6 & 11,9 & 12,8 \\
\hline & & 28 days & 62,5 & 54,8 & 80,8 & 61,8 & 64,0 \\
\hline & & 90 days & 67,4 & 69,4 & 83,0 & 64,8 & 69,7 \\
\hline Bending strength & $\mathrm{MPa}$ & 28 days & 5,4 & 4,8 & 6,9 & 7,0 & 4,8 \\
\hline Density & $\mathrm{kg} / \mathrm{dm}^{3}$ & 28 days & 2,46 & 2,41 & 2,47 & 2,39 & 2,39 \\
\hline Longitudinal wave velocity & $\mathrm{m} / \mathrm{s}$ & 28 days & 5077 & 4850 & 5056 & 4713 & 4751 \\
\hline Dynamic modulus of elasticity & $\mathrm{GPa}$ & 28 days & 67,8 & 60,4 & 67,7 & 56,6 & 57,5 \\
\hline \multirow{2}{*}{ Chloride diffusion coefficient } & \multirow{2}{*}{$10^{-12} \mathrm{~m}^{2} / \mathrm{s}$} & 28 days & 9,83 & 6,40 & 1,73 & 2,17 & 1,51 \\
\hline & & 90 days & 9,17 & 1,11 & 1,31 & 0,44 & 0,22 \\
\hline \multirow{2}{*}{$\begin{array}{c}\text { Capillary absorption coefficient, } \\
\text { after } 1 \mathrm{~h}\end{array}$} & \multirow{2}{*}{$\mathrm{kg} / \mathrm{m}^{2} \mathrm{~h}^{0,5}$} & 28 days & 1,09 & 0,90 & 0,65 & 0,60 & 0,44 \\
\hline & & 90 days & 0,55 & 0,40 & 0,42 & 0,28 & 0,26 \\
\hline \multirow{2}{*}{$\begin{array}{c}\text { Capillary absorption coefficient, } \\
\text { after } 24 \mathrm{~h}\end{array}$} & \multirow{2}{*}{$\mathrm{kg} / \mathrm{m}^{2} \mathrm{~h}^{0,5}$} & 28 days & 0,63 & 0,43 & 0,37 & 0,25 & 0,23 \\
\hline & & & 0,31 & 0,26 & 0,28 & 0,23 & 0,20 \\
\hline
\end{tabular}


6. Diagrams showing capillary absorption obtained by testing at 28 and 90 days are presented in Figures 3 and 4.

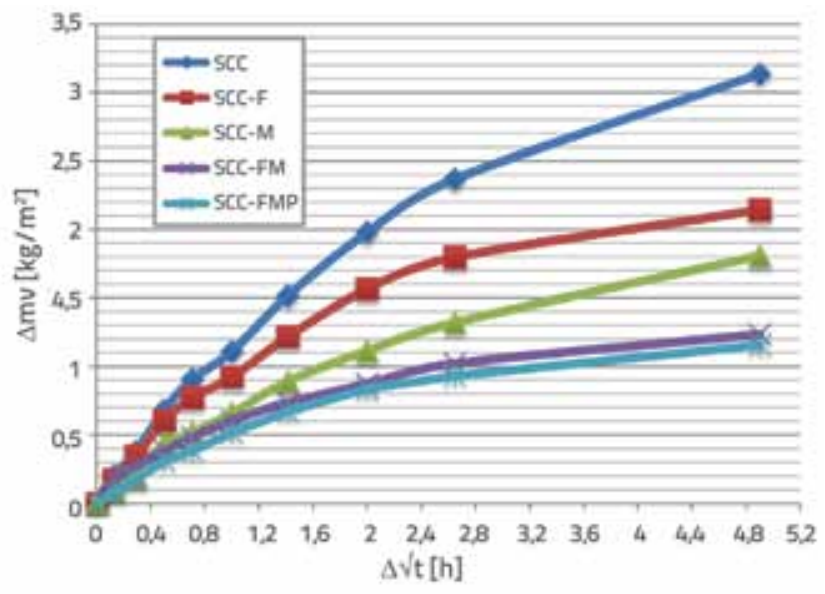

Figure 3. Graphical presentation of capillary absorption at 28 days

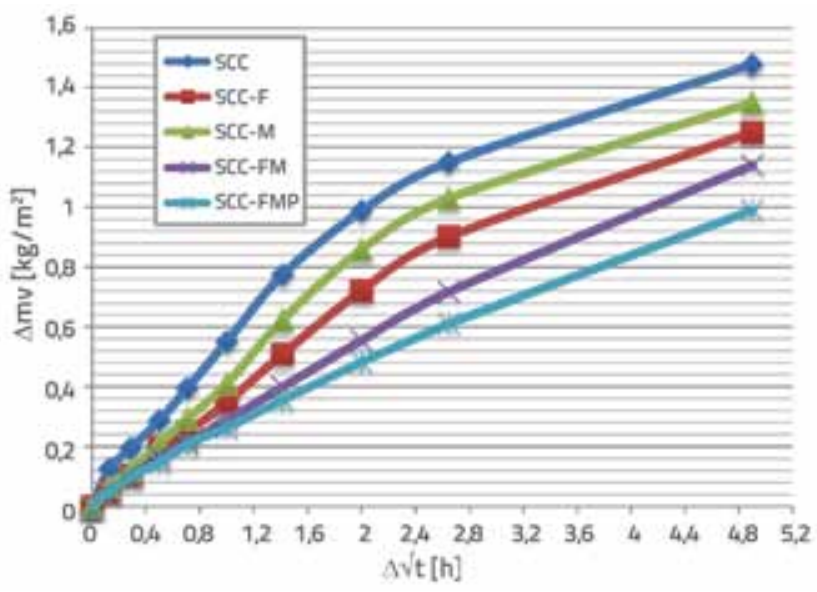

Figure 4. Graphical presentation of capillary absorption at 90 days

\section{Analysis of test results}

\subsection{Influence of fly ash on self-compacting concrete properties}

If $45 \%$ of fly ash by cement weight is added to the selfcompacting concrete, the compressive strength of concrete is reduced at 1 and 28 days, while it is increased at 90 days. The compressive strength of the self-compacting concrete with $45 \%$ of fly ash by cement weight reduces after 1 day by 47 percent, and by 12 percent after 28 days, while after 90 days the compressive strength exceeds by 3 percent that of the self-compacting concrete without fly ash. These results are explained by pozzolanic reaction of fly ash that takes place after hydration of cement. After a longer time period, the concrete with fly ash can, with proper cure, attain mechanical properties of concrete without fly ash.

Test results obtained in hardened state show that the density in the hardened state reduces when fly ash is added into the self-compacting concrete. The fly ash greatly improves durability properties with respect to the chloride diffusion and water absorption coefficients. When added to the selfcompacting concrete, the fly ash greatly improves durability properties at 90 days, when compared to such properties at 28 days.

\subsection{Influence of metakaolin on self-compacting concrete properties}

The compressive strength of the self-compacting concrete with 10 percent of metakaolin reduces after one day by 4 percent, increases by $29 \%$ at 28 days, and increases by $23 \%$ at 90 days, when compared to the self-compacting concrete without metakaolin. The bending strength of concrete with metakaolin increases by $28 \%$. This is explained by the rise in the cement matrix homogeneity due to addition of metakaolin, although this is not shown by the dynamic modulus of elasticity test results.

The chloride diffusion coefficient is improved by 5.7 times at 28 days and by 7 times at 90 days due to addition of metakaolin into the self-compacting concrete. The coefficient of capillary absorption is greatly improved after addition of metakaolin. The results obtained show that the durability and strength properties of self-compacting concrete are greatly improved after addition of metakaolin.

\subsection{Influence of polypropylene fibres on self- compacting concrete properties}

The influence of polypropylene fibres on self-compacting concrete properties can be seen in the analysis of results shown in Table 5. When compared to the mix SCC-FM, the compressive strength of the mix SCC-FMP is greater by $8 \%$ at 1 day, $4 \%$ at 28 days, and $8 \%$ at 90 days. Unlike compressive strength where polypropylene fibres do not greatly influence concrete properties, the addition of fibres considerably improves the chloride diffusion coefficient.

\subsection{Selecting an optimum self-compacting concrete mix with mineral admixtures}

Based on the ultrasound pulse velocity results ( $>4500 \mathrm{~m} / \mathrm{s}$ ), it can be concluded that all types of self-compacting concrete belong to high-quality concretes. The greatest velocity was obtained by the mix SCC-M which also has the greatest compressive strength, and so it can reasonably be stated that the said mix is also characterized by the most homogeneous structure.

With regard to all test results for hardened state, it can be stated that the mix SCC-FMP is in fact an optimum mix. High compressive strength values at 28 and 90 days were obtained for this mix, as can be seen in Figure 5. The mix marked SCCFMP has the best values for the chloride diffusion coefficient (Figure 6) and capillary absorption coefficient at 28 and 90 
days. As mineral admixtures are mostly added to the concrete in order to improve its durability, the durability criteria in hardened state can be taken as relevant for selection of an optimum mix.

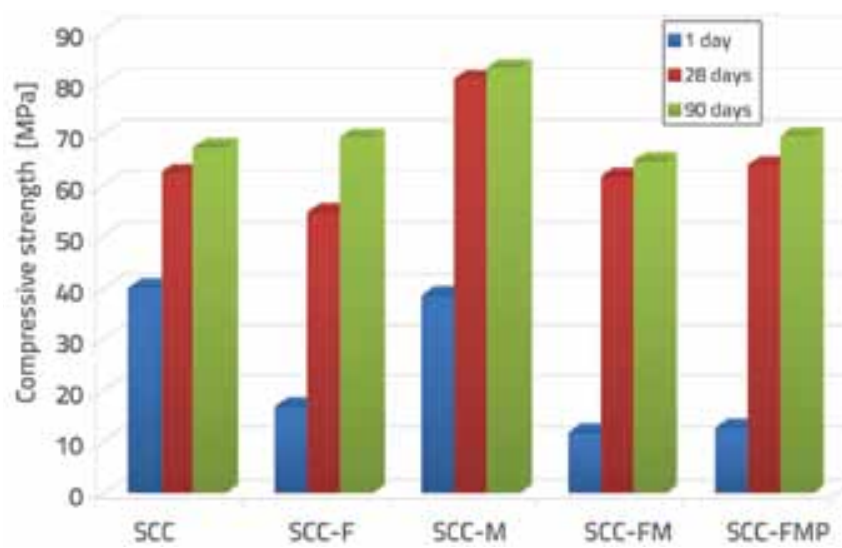

Figure 5. Compressive strength at 1, 28 and 90 days

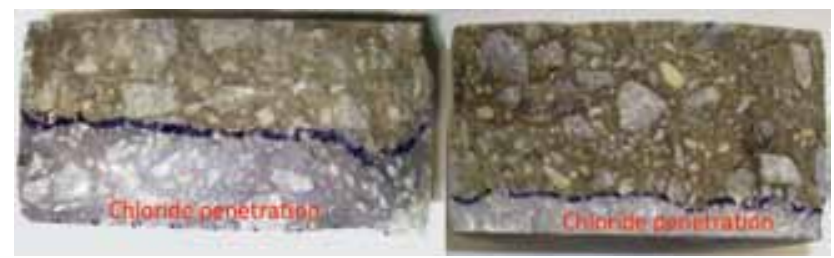

Figure 6. Chloride penetration depth for the mix SCC (left side) and mix SCC-FMP (right side)

\subsection{Influence of sample age on mechanical properties and durability of self-compacting concrete}

The greatest increase in compressive strength at 90 days, compared to 28 days ( $27 \%$ ), was registered at the mix SCC-F. The comparison of chloride diffusion coefficients for mixes

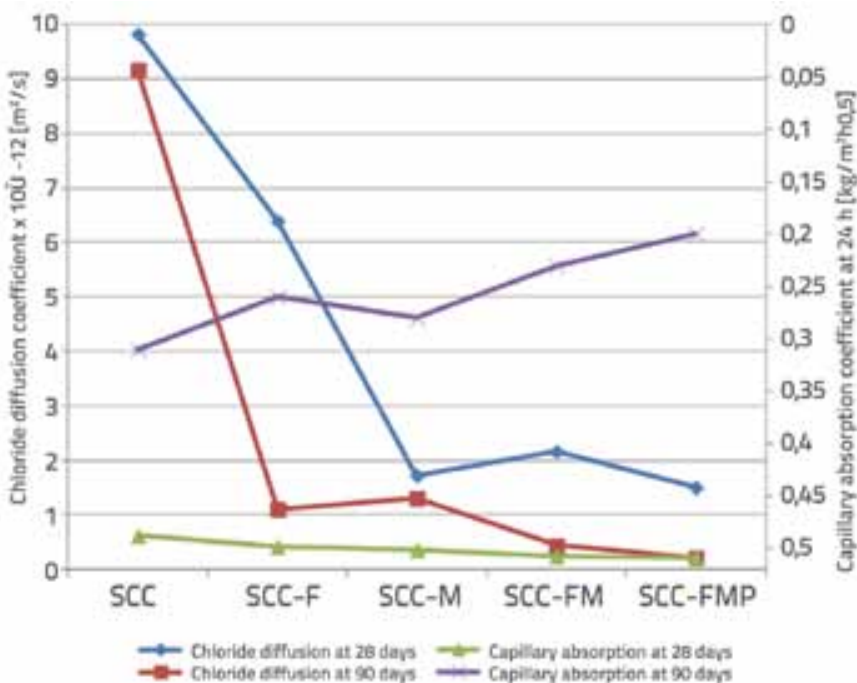

Figure 7. Comparison of chloride diffusion and capillary absorption coefficients at 28 and 90 days with admixtures has revealed that in case of the mix SCC-F the chloride diffusion coefficient was reduced by 5.8 times at 90 days with respect to 28 days, by 1.3 times in case of the mix SCC-M, by 1.1 times in case of the mix SCC, by 4.9 times in case of the mix SCC-FM, and by 6.9 times in case of the mix SCC-FMP. In addition, mixes with admixtures have attained better capillary absorption coefficients at 90 days compared to 28 days (cf. Figure 7). The smallest coefficients were attained by the mix SCC-FMP. The mix SCC-M obtained better capillary absorption coefficients at 28 days compared to mix SCC-F, while the mix SCC-F had better coefficients than the mix SCC-M at 90 days. It can be concluded from the analysis of chloride diffusion and capillary absorption coefficients that metakaolin has a greater influence on improvement of durability properties at 28 days compared to fly ash (although it is added in much smaller quantities than the fly ash), while fly ash has a greater influence on improvement of durability properties at 90 days.

\subsection{Recommended practical use of results}

Considering that the compressive strength is the only basic property of concrete, it is also necessary to define an optimum quantity of mineral admixtures (fly ash and metakaolin). At that, the intended use of the self-compacting concrete must also be taken into account. For instance, if the selfcompacting concrete is used for prefabricated prestressed concrete elements, or for the remedy of degraded reinforcedconcrete structures, then it is not recommended to use the self-compacting concrete with a higher fly ash content. In such cases, the use of self-compacting concrete with metakaolin, or without any admixtures, is recommended.

On the other hand, a greater quantity of fly ash is desirable as it can reduce hydration heat during concreting of massive concrete elements. The self-compacting concrete to be used in an aggressive environment should be improved by metakaolin, or by the fly ash and metakaolin combination.

The self-compacting concrete with fly ash, metakaolin and polypropylene fibres is recommended for aggressive environments, and especially for unfavourable thermohygrometric conditions due to the ability of polypropylene fibres to reduce green concrete cracking. Besides the above mentioned, the addition of mineral admixtures (fly ash and metakaolin) also reduces the quantity of cement in concrete, which is a direct contribution to the reduction of $\mathrm{CO}_{2}$ emissions. It can therefore be said that this type of self-compacting concrete is environmentally acceptable for use in civil engineering.

For all above mentioned applications, one should also take into account the advantages that are gained through the use of the self-compacting concrete technology, when compared to ordinary concrete.

One of obstacle hindering a wider use of metakaolin is the lack of standard that would specify the properties, control of conformity, and other parameters relating to this material. 
The study conducted in this paper shows that the addition of metakaolin greatly improves certain properties of concrete, which is an important reason for speeding up the process aimed at adoption of the metakaolin standard.

\section{Conclusion}

After analysis of results obtained by testing properties of the self-compacting concrete with different mineral admixtures (fly ash, metakaolin), designed for environmental exposure classes $X C 4, X S 3, X D 3$, the following conclusions can be made:

- Based on results obtained by testing mixes in fresh state, it was established that the influence of mineral admixtures on the workability, passing ability, filling ability and resistance to segregation, is quite visible. The selfcompacting concrete with admixtures is characterized by better properties compared to similar self-compacting concrete without admixtures.

- The compressive strength testing has revealed a considerable influence of fly ash on the reduction and in case of metakaolin, on the increase, of compressive strength at 28 days, but also on the reduction after 1 day.

- The self-compacting concrete with admixtures has a better capillary absorption coefficient and a better chloride diffusion coefficient, when compared to the self- compacting concrete without admixtures, for similar water binding ratio and binder quantity.

- The metakaolin improves durability of self-compacting concrete at 28 days to a greater extent than the fly ash, although it is added in a much smaller quantity than the fly ash.

- The fly ash improves the durability of the self-compacting concrete at 90 day to a greater extent than the metakaolin.

- Through addition of mineral admixtures, the selfcompacting concrete has become a more environmentally acceptable material due to reduced quantity of cement, which results in smaller $\mathrm{CO}_{2}$ emissions into atmosphere during cement production.

- The addition of polypropylene fibres into the selfcompacting concrete mix containing the fly ash and metakaolin improves the chloride diffusion coefficient.

The possibility of combining mineral admixtures in the self-compacting concrete opens up new areas for practical application. One of significant preconditions for this is the establishment of a uniform standard for metakaolin.

The results presented in this paper were obtained in the scope of the research project: Modern Test Methods for Construction Materials, project No. 082-0822161-2996, conducted under the auspices of the Ministry of Science, Education and Sport of the Republic of Croatia.

\section{REFERENCES}

[1] Skazlić, M.: Hibridni mikroarmirani betoni visokih uporabnih svojstava, magistarski rad, Gradevinski fakultet Sveučilišta u Zagrebu, Zagreb, 2003.

[2] Beslać, J., Skazlić, M., Kindij, A.: Posebni betoni, Betonske konstrukcije-gradenje, Secon, Andris, HDGK, Hrvatska sveučilišna naklada, Gradevinski fakultet Sveučilišta u Zagrebu, Zagreb, 2007, 262-268.

[3] Skarendahl, A.: Changing concrete construction through use of self-compacting concrete, Proceedings of the First International Symposium on Design, Performance and Use of Self-Consolidating Concrete, Changsha, Hunan, Kina, 2005, 17-24.

[4] Bartos, P.J.M.: Testing-SCC: Toewards new european standards for fresh SCC, Proceedings of the First International Symposium on Design, Performance and Use of Self-Consolidating Concrete, Changsha, Hunan, Kina, 2005, 25-46.

[5] Brouwers, H.J.H., Radix, H.J.: Self-Compacting Concrete: Theoretical and experimental study, Cement and Concrete Research 35 (2005) 11, 2116-2136.

[6] Vujica, M.: Samozbijajući ekološki održivi betoni, studentski rad za Rektorovu nagradu, Gradevinski fakultet Sveučilišta u Zagrebu, 2011.
[7] Association Française de Génie Civil: Bétons AutoPlaçants-Recommandations provisoires, Documents scientifiques et techniques, 2000.

[8] De Larrard, F.: Concrete Mixture Proportioning: a Scientific Approach, Modern Concrete Technology Series, E \& FN Spon, London and New York, 1999.

[9] Billberg P.: Self-compacting concrete for civil engineering structures-the Swedish experience, CBI Report, Swedish Cement and Concrete Research Institute, Stockholm, Sweden, 1999.

[10] Grunewald, S.: Performance based design of selfcompacting fibre reinforced concrete, disertacija, University of Delft, Nizozemska, 2004, ISBN: 90-4072487-3.

[11] Zhu, W., Bartos, P.J.M.: Microstructure and properties of interfacial transition zone in SCC, Proceedings of the First International Symposium on Design, Performance and Use of Self-Consolidating Concrete, Changsha, Hunan, Kina, 2005, 319-328.

[12] Khatib, J.M.: Performance of self-compacting concrete containing fly ash, Construction and Building Materials 22 (2008) 9, 1963-1971. 
[13] Xie, Y., Liu, B., Yin, J., Zhou ,S.: Optimum mix parameters of high-strength self-compacting concrete with ultrapulverized fly ash, Cement and Concrete Research 32 (2002) 3, 477-480.

[14] Sonebi, M.: Medium strength self-compacting concrete containing fly ash: Modelling using factorial experimental plans, Cement and Concrete Research 34 (2004) 7, 11991208.

[15] Sukumar, B., Nagamani, K., Srinivasa, R.: Evaluation of strength at early ages of self-compacting concrete with high volume fly ash, Construction and Building Materials 22 (2008) 7, 1394-1401.

[16] Skazlić, M., Rosković, R., Banjad Pečur, I.: Svojstva samozbijajućeg betona s velikim udjelom letećeg pepela, Gradevinar 60 (2008) 11, 945-952.

[17] Yazici, H.: The effect of silica fume and high-volume Class C fly ash on mechanical properties, chloride penetration and freeze-thaw resistance of self-compacting concrete, Construction and Building Materials 22 (2008) 4, 456-462.
[18] Okamura, H., Maekawa, K., Ozawa, K.: High Performance Concrete, Gihoudou Pub, Tokyo, Japan, 1993.

[19] Cassagnabere, F., Mouret, M., Escadeillas, G., Broillard P., Bertrand „A.: Metakaolin, a solution for the precast industry to limit the clinker content in concrete: Mechanical aspects, Construction and Building Materials 24 (2010) 7, 1109-1118.

[20] Vejmelkova, E., Keppert, M., Grzeszczyk, S., Skalinski, B., Černy, R.: Properties of self-compacting concrete mixtures containing metakaolin and blast furnace slag, Construction and Building Materials 25 (2011) 3, 1325-1331.

[21] Guneyisi, E., Gesogku, M., Ozbay, E.: Strength and drying shrinkage of self-compacting concretes incorporating multi-system blended mineral admixtures, Construction and Building Materials 24 (2011) 10, 1878-1887.

[22] Siddique, R., Klaus, J.: Influence of metakaolin on the properties of mortar and concrete: A review, Applied Clay Science 43 (2009) 3-4, 392-400. 

Primljen / Received: 19.1.2012. Ispravljen / Corrected: 19.6.2012.

Prihvaćen / Accepted: 24.8.2012.

Dostupno online / Available online: 15.12.2012.

\section{Research of asphalt layer bonding in Lithuanian pavement structures}

Autori:

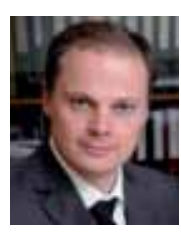

Prof. Audrius Vaitkus audrius.vaitkus@vgtu.It

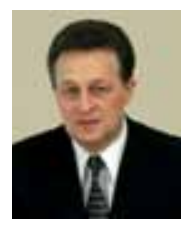

Prof. Donatas Čygas donatas.cygas@vgtu.It

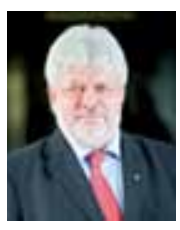

Prof. Alfredas Laurinavičius alfredas.laurinavicius@vgtuu.It

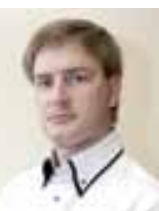

${ }^{1}$ Viktoras Vorobjovas viktoras.vorobjovas@vgtu.It

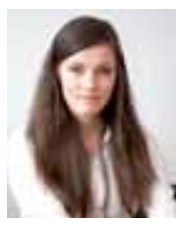

${ }^{1}$ Rita Kleizienè, PhD student rita.kleiziene@vgtu.It

${ }^{1}$ Roads Research Institute

Vilnius Gediminas Technical University, Lithuania

${ }^{2}$ Department of Roads

Vilnius Gediminas Technical University, Lithuania

\begin{abstract}
Preliminary note
Audrius Vaitkus, Donatas Čygas, Alfredas Laurinavičius, Viktoras Vorobjovas, Rita Kleizienẻ
\end{abstract}

\section{Research of asphalt layer bonding in Lithuanian pavement structures}

The strength and durability of road pavement structures are directly influenced by the way in which asphalt layers are bonded. An insufficient bond between pavement layers leads to wearing, tearing, pavement deterioration, and cracking, and the pavement life span is reduced. The quality of bond between pavement layers was determined by direct shear test, using the so called Leutner method, without normal stress in specimen. Test samples were taken at various locations along the Lithuanian road network, from pavements characterized by standard asphalt structure, and reinforced asphalt structure in which geosynthetic materials are used in interlayers

\author{
Key words: \\ asphalt pavement, bond between pavement layers, Leutner method
}

Prethodno priopćenje

Audrius Vaitkus, Donatas Čygas, Alfredas Laurinavičius, Viktoras Vorobjovas, Rita Kleizienè

\section{Istraživanje veziva asfaltnih slojeva kolničkih konstrukcija u Litvi}

Način povezivanja slojeva asfaltne kolničke konstrukcije izravno utječe na čvrstoću i trajnost kolnika. Ako veza nije pravilno izvedena, kolnik postaje sklizak, dolazi do habanja, pucanja, propadanja kolnika i pojave pukotina te smanjenja vijeka trajanja. Kvaliteta veze između slojeva kolnika odredena je direktnim ispitivanjem na smicanje, takozvanom Leutnerovom metodom bez pojave normalnog naprezanja u uzorku. Uzorci za ispitivanja uzeti su na različitim lokacijama cestovne mreže u Litvi, i to iz kolnika s klasičnom asfaltnom konstrukcijom te s pojačanom asfaltnom konstrukcijom primjenom geosintetika u međuslojevima.

Ključne riječi:

asfaltni kolnik, veza slojeva kolničke konstrukcije, Leutnerova metoda

Vorherige Mitteilung

Audrius Vaitkus, Donatas Čygas, Alfredas Laurinavičius, Viktoras Vorobjovas, Rita Kleizienè

\section{Untersuchung des Verbunds von Asphaltschichten in litauischen Fahrbahnstrukturen}

Der Verbund von Asphaltschichten der Fahrbahnstruktur hat einen direkten Einfluss auf die Festigkeit und die Haltbarkeit der Fahrbahn. Unsachgemäß ausgeführte Schichtenverbunde können eine rutschige Oberfläche der Fahrbahn verursachen, während möglicherweise auftretende Verschleißung, Rissbildung und andere Beschädigungen zu einer Verringerung der erwarteten Lebensdauer führen können. Die Qualität der Schichtenverbunde des Straßenbelags ist durch Abscherversuche ermittelt, mit Hilfe der sogenannten Leutner-Methode, die ohne das Auftreten von Normalspannungen ausgeführt wird. Versuchsproben sind an verschiedenen Standorten des Straßennetzes in Litauen entnommen worden, und zwar sowohl für Fahrbahnen mit klassischen Fahrbahnstrukturen, als auch für Asphaltbeläge, die durch die Anwendung von geosynthetischen Materialen in den Zwischenschichten verstärkt wurden.

Schlüsselwörter:

Asphaltfahrbahn, Schichtenverbunde der Fahrbahnstruktur, Leutner-Methode 